\title{
Supply Side Structure Problems of the Vocational College English Education and Its Breakthrough
}

\author{
Yanqing Song \\ Department of Foreign Language \\ Changzhou College of Information Technology \\ Changzhou, China
}

\begin{abstract}
English education has been a short board of civil vocational colleges, and even some English majors, such as commercial English, also can't achieve the standard of social demand. This status has directly influenced the vocational college's cultivation quality, and reacted in a chain to the vocational college enrollment situation, especially English majors' enrollment has been impacted greater and many English majors have been forced to stop or decrease recruit students, which leads to serious overcapacity of the vocational college English education. However, on the one hand, English majors' recruit students number in the vocational college is shrinking, and on the other hand, societies can't hire enough appropriate English talents of the vocational college. The root to such unbalance of talents supply and demand is owing to supply side structure problems which give rise to supply and demand dislocation of the vocational college talents. Therefore, the vocational college English education supply side structure should be reformed, and factors or system supply of the vocational college English education supply side should be optimized, so as to actually improve vocational college students' English application ability, which is the only important link to break through the students resource crisis and English majors' shrinking.
\end{abstract}

Keywords—vocational college; supply side; structure problem; breakthrough

\section{The SupPly Side StRUCTURE PROBlem AND ITS REFORM}

\section{A. Supply Side and Demand Side}

Supply and demand are two basic concepts in Economics. Supply means the manufacturer provides products, and demand means the customer needs products. The supply side refers to the various input factors and process of operation. The main input factors include labor, land, capital and entrepreneurship, etc.. The process of operation includes optimization and combination of production factors, process design and re-engineering, system design, etc.. The demand side refers to consumers consuming products. The supply level depends on the quality of the supply side factor inputs and the operation efficiency, while the demand level depends on demand types of the demand side, demand preferences, demand substitution, demand strength, demand extension, etc.. The balance of supply and demand means quantity and quality of products of the supply side accords exactly with that of the demand side, while the unbalance of supply and demand means quantity or quality of products of the supply side does not match that of the demand side, such as an excess of supply, a short supply, an improper supply, or a dislocation supply, etc..

\section{B. Supply Side Structure Problem Reform}

There are two reasons of the unbalance between supply and demand. One is the cause of the supply side, and the other is of the demand side. The cause of the supply side may be in many aspects, such as low quality of the inputs, improper combination of elements, unscientific process design, backward production method, defective management system, and so on.[1] The cause of the demand side may be in many aspects, such as demand preference changes, demand substitution increases, demand capacity becoming lower, and so on.

There are three ways to handle the unbalance problem of supply and demand. The first is to reform the supply side to fit the demand side, [2] the second is to manage the demand side to adapt to the supply side, and the third is to make force in both the supply side and the demand simultaneously making them adjust to each other.In specific market conditions, the choice of appropriate governance is extremely important.

\section{VocATIONAL ENGLISH EdUCATION SUPPLY SIDE STRUCTURE PROBLEMS}

\section{A. Vocational English Education Supply Side and Demand Side}

If education is also regarded as a kind of output process, the products of Vocational education are students. Of course, the student is a kind of "input", a "raw material", but the newly enrolled students are not the same as the graduates. Graduates are more mature and master a lot of technology and skills than students in school. Accordingly, the vocational supply is to transport the vocational talents to society, and the vocational demand is the social needs of the vocational talents, including quantity, quality, specifications, etc..

The supply side of vocational English education refers to vocational colleges supplying vocational English education, whose input factors mainly include English teachers, students, teaching facilities, English education programs, teaching outline, teaching plan, curriculum standards, 
textbooks and other curriculum resources package, teaching management system... And so on... The demand side of vocational English education refers to students, parents, social enterprises and institutions needing vocational English education. The healthy development of vocational education depends on either the balance between the quantity of the vocational education supply and the vocational education demand or the matching between the quality of vocational education supply and the Vocational education demand.

\section{B. Necessity to Reform Vocational English Education Supply Side Structure}

For the present China vocational education, on the one hand, vocational colleges hold adequate teachers and excellent teaching appliance, and have occupied half scale of Chinese higher education, and emerge severe excess production capacity, but on the other hand, most higher school students would rather crowd to the ordinary colleges and universities domestic or abroad than enter vocational colleges. This shows that although in recent years the number of higher students tends to be at a lower and lower stage periodically, the demand of higher education is still very strong, so the problem of demand side of vocational education is not prominent and the supply side structural problem of vocational education is the principal contradiction of the vocational education. The key links to break through student resource crisis and shrinking of English majors is to distinguish the supply side structural problems of vocational education and then reform the supply side structure of vocational English education.

\section{Vocational English Education Supply Side Structure Problems}

1) Teachers Supply Problem:Only the first class teachers can cultivate first-class talents. To vocational English education, the first class teachers not only show high level of English, but also need to consider the actual situation and the social reality needs and use effective methods and means to arouse students' interest in learning English, and effectively improve the students' practical English skills, because vocational education is not academic education but "employment-oriented" education. The significance of learning vocational English is neither to learn English nor absorb messy knowledge. Vocational English education should not cultivate the incomprehensible "deaf", or the invisible "blind", or the "dumb". Vocational English education should not blindly create foreign situation to cultivate foreigners. Vocational English education must combine with Chinese actual situation and tell Chinese stories using words that foreigners can understand, or be able to introduce foreign advanced civilization achievements and make them of our own achievements by analyzing, deconstructing them.

Practical English skills lie in four aspects, namely listening, speaking, reading and writing, but the first important aspects are listening ability and speak ability, because as a means of communication, listening and speaking are the most direct and immediate interactive feedback, so English listening and speaking ability is certain to promote English reading and writing interest in learning, and the poor ability of listening and speaking training is the "dumb English" teaching mode, which leads to students' unsustainable interest in learning English. But the present reality is that most English teachers can't communicate and dialogue in complete English context or don't used to doing so, not to mention that they have to lead a class of students whose English listening and speaking level is relatively weak. In vocational English education, it is extremely rare for English teachers to insist on teaching in full English scene, as is the biggest obstacle to the supply side of vocational English education.

2) Students Resource Supply Problems:Since the Ministry of Education issued "guidance on actively promoting the reform of the separate examination of enrollment from common four year undergraduate program", the admission forms of vocational colleges have evolved a variety of ways, such as ordinary college entrance examination, separate admissions, vocational college entrance examination for secondary vocational schools, registration of enrollment, enrollment exempted from examination, etc.. In the future there will be more ways. At the same time, the status of vocational college students is becoming more and more complex. Some will come from the high school, some from secondary vocational schools or vocational high schools, and others from soldiers or members of the community. Some will come from the developed region and others from undeveloped or backward areas. Some will come from foreign countries, and so on. So students' English level is uneven, which brings great challenges for traditional highly consistent teaching methods of vocational English education. In addition, students' graduation direction also shows a pattern of diversification. Some will choose employment, some will choose entrepreneurship, some will choose joining army, and others will choose going to study in four year universities domestic or abroad. Obviously, different graduation directions require different students' English level, so professional English education should carry out according to students' graduation flow direction.

In a period of rapid development of industrial economy, with the personalized characteristics of product demand and huge differences in sources of raw materials, the traditional type of production process of large assembly line didn't adapt to the development of the times, and the customer customized patterns with small-volume, flexible and personalized features came into being. Similarly, in the face of huge differences of students resource, students' English basis and requirements of English level to different graduation flows, vocational English teaching methods and teaching moles must also keep pace with the times and make a great reform, so as to adapt to changes in market demand for talents.

3) Teaching Resource Supply Problems:The supply of vocational English education resources is another factor that 
restricts the quality of vocational English education. After years' construction of teaching resources and teaching facilities, in terms of quantity, supply of vocational English education resources have been quite sufficient, not only with a lot of teaching materials, multimedia courseware exquisite, but also with the introduction of foreign original textbooks. Besides, multimedia classrooms, language rooms, training rooms and other teaching facilities are also available. However, in terms of quality, these seemingly high-quality educational resources only play extremely limited roles. Because most of these resources are not built by teachers themselves, the teachers themselves are not familiar with using these teaching resources. They must try first to learn to use these resources, then, to teach students. Generally, teachers have to take so much time as to master these resources, but they have not enough time. In addition, because the production or creation of these resources are completely based on the scene of English speaking countries, most materials are present in the English speaking countries' political, economic and cultural background, but they are neither connected with Chinese peculiar culture, nor with the diversification of students' future occupation or the diverse needs of society. China vocational education' goal is to teach students to tell Chinese story in standard English. It is too difficult for students to learn English in limited English class time, not alone understand and be familiar with English speaking countries' politics, economy, culture and customs at the meantime. English speaking countries' scene, politics,economy, customs and their thinking way are all strange to students. the complex English word order and grammar are also strange to students. Therefore, to ask students to learn both English expression and English countries' scene will inevitably tend to make students care for this and lose that, and the result is that they lose both. To teach students to speak in English Chinese things close to their routine life is more likely to cause students' interest, which is more helpful to vocational English education. Above all, the supply of vocational English education resources needs to be optimized, simplified, sinicized and vocational.

In addition to the quality of resources to be improved, the excess supply of resources, including teachers, is also a problem of overcapacity in vocational English education.

4) Management System Supply Problems:At present, before graduation, vocational students' English requirements is that they must pass a vocational English Class A or B examination. But such a unified requirement is with some evident drawbacks. Because the vast majority of students are able to pass a vocational English Class A or B test, but their actual ability to practice English is still very poor, the vast majority of students still can not communicate in English. In fact, different types of students have different English basis, and students flowing to different graduation direction require different level of English, so the unified training target design does not meet all students' future requirement for English and vocational English Education management system must be reformed.

\section{BREAKTHROUGH OF VOCATIONAL ENGLISH EDUCATION SUPPLY SIDE STRUCTURE PROBLEMS}

\section{A. Enhance Teachers Supply Quality}

It is necessary to cultivate teachers domestically and introduce foreign talents to improve the whole English education level, especially the ability of teaching with the full English context. Language learning cannot do without the specific language environment, therefore, English teachers should be sent to the University at home and abroad for specialized English or English proficiency training during the summer vacation or other entire time as far as possible.

Many vocational schools have introduced a number of foreign teachers, but the foreign teachers don't play a sufficient role. Usually, not only the students rarely communicate and interact with foreign teachers, but also the school's English teachers do similarly. Many English teachers seem much strange to foreign teachers and even when they happen to meet in road, they also just greet each other with few words or simply a nod. This situation must be changed completely. The number of foreign teachers who come to the vocational college is very small. In daily, they must be very lonely and are eager to communicate with Chinese, and the most important thing is that Chinese can get more in this kind of communication, during which Chinese can continuously stimulate their sense of language, gradually learn to think and express in English, eliminate the fear of English, and all of these are the threshold Chinese must cross in learning English.

In addition to spare time when English teachers and students need to close and communicate with foreign teachers frequently, classroom time is more important. It is suggested that the vocational English teachers and foreign teachers should prepare lessons together and teach together, rather than vocational English teachers just sit in foreign teachers' classroom silently and imitate the foreign teachers in their own classroom.Participation has so completely different effect to English teaching as imitation.

\section{B. Make no social distinctions in teaching but carry out Classified Teaching Strategy}

It is generally believed that the main reason for the difficulty in improving the quality of vocational English education is students' poor English basis and poor learning ability. But this is in fact a false statement. Quite a few vocational students' English level is quite good when entering colleges, and some can even pass College English Test Band 4(CET4) in the first or second year of college, but when they enter the third year of college their CET 4 pass rate decline dramatically instead. Some people say jokingly the more to study English, the worse to learn English. There may be some problems in this statistical method, but at least it reflects in one aspect a big problem in vocational English education.

As to the phenomena of some vocational students' poor English basis and poor learning ability in reality, some 
scholars put forward the "Hierarchical Teaching" strategy, such as Bi Yongzhi (2014) who put forward arranging English course class according to English entrance test scores. Some scholars put forward the "vocational demandoriented" strategy, such as Gan Lihua (2013) who proposed to launch automotive English, computer English, chemical English, and so on[4]. Some scholars believe that vocational English should return to ability training objectives [5], such as Zhou Qun (2014) who put forward "focusing on language knowledge, general language communication and practical communicative ability". [6]

As to Hierarchical Teaching, there are three drawbacks: one is Hierarchical Teaching implies some discrimination to those students whose English basis is weak, and this discrimination will affect students' confidence in study.The second is that it assumes students with good English basis can learn English easily, but in fact, the key to learn English well depends heavily on attitude. In fact, the main training objective of vocational English education is to cultivate practical skills of English usage, so vocational English teaching content is not too much and not difficult to learn. Even if a student is poor in English, as long as he has the clear goal of learning and has good attitude, he can surely learn well. Thirdly, because students' English level has been in a dynamic change, it is difficult to carry out Hierarchical Teaching dynamically.

The "vocational demand-oriented" strategy and "abilityoriented" strategy, in fact, are of two aspects of one problem, so they should be combined. The "vocational demandoriented" strategy considers vocational education as the equivalent of vocational training, which did not reach the higher education's "higher" objectives, while the "abilityoriented" strategy, if separated from vocational demand or needs of industries, does not achieve the "vocational" objectives of the higher vocational education.

Therefore, we should make no social distinctions in teaching and carry out classified teaching strategy. First of all, it is believed that any vocational student, regardless of his English basis, is able to be taught English well; secondly, teaching contents should be organized and carry out in class according to the student resource type and his future graduation direction; finally, social vocational English training should not be missed.

Vocational students' oriented goals are nothing more than employment / Entrepreneurship, turning or going to undergraduate university, going abroad for further study, and so on. For employment / entrepreneurship students, vocational English education should focus on English practical application ability, and training objectives are "listening and speaking "firstly, and secondly "reading and writing". For students turning or going to undergraduate university, English test ability must be paid more attention to, so a lot of exercises and tests are the only way. For students going abroad for further study, IELTS, TOEFL or Pests must be chosen one to teach.

\section{Make Resource Practical and Service Socialized}

Compared with general higher education, vocational education must be paid more attention to the practice, therefore, high quality of vocational English education resources supply don't refer to great or fashionable resources, but ones with wonderful practical use, close to students' life, easy to be perceived by vocational students and easy to cause their resonance. So, high quality of vocational English education resources supply are not very complex, not necessarily exquisite or beautiful, but must be loved by the students, must keep pace with the times. According to these standards, a lot of vocational English education resources built in the past don't have such characteristics. However, if these resources are built or produced by teachers themselves, teachers will definitely give more consideration to students, social and environmental factors. We once listened to a vocational English teacher's lesson. He taught in the way of a section of the flipped classroom, teaching resources being rather simple, only with a few slides. The teacher firstly led a topic for students to discuss: Is it necessary for a company to spend a lot of money on advertisements? Then the students prepared and debated in groups. The teacher directed the discussion and gave some comments or taught some new knowledge from time to time in the course. The whole lesson was completely in full English language environment. No Chinese word was allowed to speak, and a big reminder was written on the blackboard: In English. The lesson was organized so efficiently that the students got a great harvest. Just imagine, if the lesson is still taught in the traditional way, then, even if the teacher spent much time on preparing using the beautiful courseware which is so strange to him, the lesson would not be taught so lovely and so efficiently. Because when the teacher was speaking for long, students were difficult to listen carefully from beginning to end, and the inevitable result was the common phenomenon: the students secretly play mobile phone.

In the next few years, vocational students resource will remain at a low ebb, vocational English teachers and idle teaching facilities surplus will be a big problem faced by vocational education. Some vocational colleges divert English teachers to popular vocational majors. Although this can ease the pressure of popular vocational majors' teaching task, but from a scientific perspective of human resource management, this is not a good way. On the one hand, because Difference in profession makes one feel worlds apart, so generally English teachers who have to switch to unfamiliar industries can hardly make the best of his talent. On the other hand, with the rapid development of the national economy, the social demand for English talents will become more and more, so if vocational English teachers are assigned to some export-oriented enterprises, they can not only increase their abilities, but also contribute vocational expertise service to enterprises.

The second way to solve the problem of excess capacity of vocational English education is to expand the social training, for many enterprises and institutions need English training and this is a huge English training market.

The third way to solve the problem of excess capacity of vocational English education is to arrange young teachers to 
study at home or abroad, so that vocational colleges can accumulate vocational English teachers' human capital which can help build the core competitiveness of colleges' vocational education.

\section{Implement flexible English Education Management System}

Obviously, only by changing the management system of Vocational English education, can we meet the needs of different types of students and the vocational requirements of the graduates. For the specific registration students or separate admission students, the previous vocational English class A or B level requirements can be used continuously, because these two types of students have relatively low level of English basis, besides, their majors, often correspond to some traditional industries, such as agriculture, animal husbandry and food industry where the application of English are rare somewhat. But for majors like international trade, English, business English and others, higher standards should probably be adopted, such as passing CET4 or reaching certain points for some English level exam, because this part of the students' English basis is better, and their expected future jobs require higher level of English. For vocational undergraduate, CET4 level requirements should be met. For students of Chinese foreign cooperation in running schools or those who need to study abroad, they should be required by the IELTS or TOEFL test. In a word, for the vocational students with different types of students and different requirements of English in the future, it is necessary to develop and implement a flexible Vocational English education target system.

\section{CONCLUSION}

In the period of rapid development of industrial economy, with huge differences in sources of raw materials and personalized features of product demand, the large production process of assembly line did not adapt to the development of the times, so personalized customization mode with small-volume and flexible feature came into being in time. Similarly, in the face of huge differences in complexity of vocational students resources, huge difference in students' English basis, and difference in English requirements of graduates flowing to different ways, vocational English education supply side structure should also be changed accordingly. The vocational English education objective is to teach students to tell Chinese story with standard English, so vocational English education resources including teachers, teaching materials must be optimized and simplified, sinicized and vocational, and the big and unified vocational English education supply system must be reformed and increase flexibility, so as to meet the requirements of different types of students resources and different post English requirements for vocational students flowing in all directions after graduating.

\section{ACKNOWLEDGMENTS}

This paper is Sponsored by Vocational Colleges' Foreign Major Direction Committee of Ministry of Education of the People's Republic of China (Project:GZWYJXGG-036), and the project of Jiangsu provincial excellent innovative team of philosophy and Social Sciences (Project: 2017ZSTD035). Thanks for Fund.

\section{REFERENCES}

[1] Xiao Huozhi. Supply side is the new normal economic structure adjustment [J], economy, 2015 (2): 46

[2] Yi Zhun. Supply side reform: institutional innovation with the crisis [J], China economy report, 2016 (1): 16-18.

[3] Jia Kang. Deepening the reform of supply and releasing the potentia of China [J], China economy report, 2016 (2): 47-50.

[4] Bi Yongzhi. To deal with the differences in the level of vocational Colleges[J]. Journal of educational science of Hunan Normal University, 2014 (11): 125-128.

[5] Gan Lihua. English teaching reform with the vocational demandoriented way[J], Journal of Ningbo College of education, 2013 (4): 79.

[6] Zhou Qun. The study of College English teaching model based on the analysis of diversified needs [J], radio and TV University, 2014 (4) 55-56. 